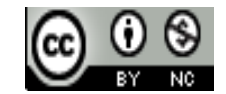

Jurnal Pendidikan Matematika Indonesia is licensed under A Creative Commons Attribution-Non Commercial 4.0 International License.

\title{
Pengaruh Penggunaan Strategi Pembelajaran Aktif ICM (InDeX CARD MATCH) TERHADAP HASIL BELAJAR MATEMATIKA
}

\author{
Erlando Doni Sirait ${ }^{1)}$, Dwi Dani Apriyani ${ }^{2)}$ \\ 1) Universitas Indraprasta PGRI, Jakarta, Indonesia \\ E-mail: erlandodoni19@gmail.com \\ 2) Universitas Indraprasta PGRI, Jakarta, Indonesia \\ E-mail: dwidani12@gmail.com
}

\begin{abstract}
Abstrak. Berhasilnya pembelajaran tergantung bagaimana seorang guru mengelola suasan kelas dan pemilihan suatu metode yang dipergunakan dalam pembelajaran yang tepat, sehingga tentu saja dapat mempengaruhi suasana pembelajaran dan hasil belajar siswa. Digunakannya strategi pembelajaran dengan sesuai maka siswa akan ikut berperan aktif pada proses belajar sehingga belajar dan mengajar akan lebih optimal. Optimalisasi proses belajar dan mengajar akan berdampak baik terhadap hasil belajar siswa. Beberapa mata pelajaran yang menggunakan perhitungan seperti matematika akan terlihat jelas bahwa siswa yang melakukan proses belajar dengan aktif maka akan lebih memahami dibandingkan siswa yang pasif. Strategi pembelajaran aktif ICM (Index Card Match) yang dilakukan dengan cara yang menyenangkan dapat membantu guru menciptakan suasana kelas yang aktif bagi siswa. Dengan menerapkan strategi pembelajaran aktif ICM (Index Card Match) siswa dapat diberikan catatan dan tugas untuk mempelajari materi secara mandiri sebelum jam pelajaran kelas dimulai. Dalam penggunaan strategi pembelajaran ICM (Index Card Match) ini, diharapkan agar siswa dapat lebih tertarik terhadap proses pembelajaran matematika dan pada akhirnya akan memberi hasil belajar matematika yang tinggi pada siswa. Mencari tau seberapa jauh perubahan yang terjadi dengan diberlakukannya strategi pembelajaran aktif ICM (Index Card Match) terhadap hasil belajar matematika adalah tujuan dari penelitian yang dilakukan. Dan hasil uji hipotesis menunjukan bahwa terdapat pengaruh penerapan strategi pembelajaran aktif ICM (Index Card Match) terhadap hasil belajar matematika. Dengan dilakukannya penelitian ini semoga dapat menjadi sumber referensi untuk melakukan penelitian baru dan dapat bermanfaat bagi guru untuk lebih melakukan inovasi dalam mengembangkan metode dan media pembelajaran. Dan dapat digunakan sebagai referensi untuk penelitian lanjutan, dengan judul yang sama namun metode, model, teknik analisis ataupun sampel yang berbeda, sehingga didapat sebuah temuan baru yang berguna untuk kemajuan ilmu pengetahuan, khususnya untuk memperbaiki kualitas pendidikan di Indonesia.
\end{abstract}

Kata kunci: Strategi Pembelajaran, ICM (Index Card Match), Hasil Belajar Matematika

\section{Pendahuluan}

Banyak faktor yang menyebabkan timbulnya masalah yang akan terjadi pada proses belajar dan mengajar, khususnya pelajaran matematika. Salah satunya adalah pemikiran siswa mengenai pelajaran matematika yang sulit dan membosankan karena selalu berhubungan dengan rumus dan soal. Hal ini diakui oleh Siregar (2017) bahwa akan adanya dampak buruk bagi siswa jika banyaknya anggapan bahwa matematika sulit untuk dipahami. Anggapan siswa yang merasa bahwa mata pelajaran matematika tidak relevan pada kehidupannya, melihat fenomena ini sangat disayangkan jika matematika selalu dijadikan pelajaran yang dihindari hanya karena pemikiran awal siswa yang tertanam sudah negatif. Sehingga disini peran guru sangat dibutuhkan, guru tidak sebatas mampu menguasai materi yang hendak diajarkan namun tetapi guru harus mampu menjadikan kondisi kelas yang menyenangkan saat pembelajaran matematika sehingga siswa dapat ikut aktif saat mengikuti pembelajaran. Seperti yang dijelaskan oleh bahwa (Jaya, 2017) salah satu kemampuan seorang guru ialah mampu menjadikan suasana kelas menjadi gembira.

Proses penyapaian materi oleh guru kepada siswa memerlukan suatu strategi pembelajaran guna memudahkan guru mencapai tujuan pembelajaran (Anggraeni, 2019). Pemilihan strategi pembelajaran yang tepat oleh guru tentu akan mempengaruhi suasana kegiatan belajar dan akan berdampak baik pada hasil belajar, hal ini juga sesuai dengan ahli (Barlian, 2013) tentang proses belajar dan mengajar hal penting yang harus dipersiapkan oleh guru ialah mengatur 
kondisi kelas, kondisi siswa sehingga sesuai dengan materi ajar dan menjadikan proses belajar dan mengajar lebih maksimal dan siswa mampu menerima dengan baik dan mampu mensukseskan upaya dalam meningkatkan efektifitas proses belajar dan mengajar sehingga akan adanya kegiatan aktif seperti tanya jawab dari siswa, terciptanya proses belajar dan mengajar yang optimal, dan dapat meningkatkan hasil belajar siswa. Dari hal di atas, diharapkan guru mampu melakukan strategi pembelajaran yang sukses dalam meningkatkan nilai pemahaman konsep serta hasil belajar siswa yang salah satu strateginya adalah pembelajaran yang dijadikan alternatif maupun variasi dalam pembelajaran matematika adalah strategi pembelajaran aktif ICM (Index Card Match).

Strategi pembelajaran aktif ICM (Index Card Match) ialah pengambilan keputusan atas cara belajar yang mampu membuat siswa senang sehinggasiswa mampu mengulang materi yang diajarkan dan merasa senang dengan tugas yang diberikan serta mampu mempelajari materi sendiri sebelum kegiatan belajar dimulai (Zaini, Munthe and Aryani, 2007). Dengan diterapkannya strategi pembelajaran ICM (Index Card Match) ini, diharapkan agar siswa dapat lebih tertarik terhadap proses pembelajaran matematika sehingga siswa mampu belajar lebih focus dan hasil belajar yang diperolehnya tinggi. Mengingat strategi ini dapat menciptakan sebuah proses proses belajar dan mengajar yang lebih menyenangkan, sehingga siswa lebih fokus terhadap materi.

Berdasarkan hal yang disampaikan di atas, permasalahan yang ada akan diselesaikan dengan menerapkan strategi aktif ICM (Index Card Match) terhadap hasil belajar matematika

\section{Metode PEnelitian}

Penelitian eksperimen ini dilakukan dengan mengambil populasi target pada siswa SMP Uswatun Hasanah, sedangkan pengambilan sampel dengan menggunakan sampling jenuh dan memberikan perlakuan pada dua kelas yang diberi nama kelas kontrol dan kelas eksperimen. Pengambilan sampel yang menggunakan seluruh populasi sebagai sampel disebut dengan sampling jenuh. Ukuran sample sebanyak 35 siswa yang belajar dengan menggunakan strategi pembelajarn aktif ICM dan sebanyak 35 siswa yang belajar menggunakan strategi konvensional. Mengambil data hasil belajar matematika siswa yang telah mendapat pembelajaran menggunakan strategi pembelajaran aktif ICM serta strategi pembelajaran konvensional Ekspositori, dilakukan test berbentuk objektif dengan total jumlah soal 20 nomor.

Pada penelitian ini perlakuan diberikan kepada kelompok siswa yang mendapat pembelajaran menggunakan strategi pembelajaran aktif ICM. Perlakuan diberikan selama 4 kali pertemuan, dimana setiap pertemuan adalah 2 jam pelajaran ( 2 x 40 menit) sesuai dengan jadwal yang terdapat pada sekolah tersebut. Mengingat banyak faktor yang mempengaruhi kualitas pembelajaran di kelas yaitu antara lain: instrument pembelajaran berupa rencana pembelajaran yang meliputi kompetensi dasar, evaluasi, guru, siswa dan kondisi kelas agar kedua kelompok yang diberikan perlakuan mempunyai karakteristik yang mendekati sama, maka faktor-faktor tersebut dibuat mendekati sama kecuali strategi pembelajaran yang digunakan.

Pada akhir proses, seluruh siswa baik yang mendapatkan pembelajaran strategi pembelajaran aktif Index Card Match (ICM) maupun yang menggunakan strategi pembelajaran konvensional, diharuskan mengerjakan tes hasil pembelajarn sesuai dengan yang tertera pada rencana pembelajaran.

\section{HASIL DAN PEMBAHASAN}

Data yang telah dikumpulkan kemudian ditampilkan secara deskriptif dalam tabel dibawah ini.

TABLE I

DESKRIPSI DATA TIAP VARIABEL

\begin{tabular}{lcc}
\hline & $\begin{array}{c}\text { Kelas } \\
\text { Eksperimen }\end{array}$ & $\begin{array}{c}\text { Kelas } \\
\text { Kontrol }\end{array}$ \\
\hline Mean & 66.80 & 59.49 \\
Median & 67.00 & 62.00 \\
Range & 30 & 28 \\
Minimum & 52 & 48 \\
Maximum & 82 & 76 \\
\hline
\end{tabular}

Dari hasil tabel 1 dapat dilihat jika hasil belajar kelas eksperimen dengan kelas kontrol memiliki sebaran yang baik. Dengan pengertian jika sampel penelitian menunjukan tingkat kecerdasan yang merata (tidak terlalu pandai dan tidak terlalu kurang).

Menghitung uji kenormalan dan pengujian homogenitas sebagai syarat analisis data

TABLE III

UJI NORMALITAS

\begin{tabular}{lcc}
\hline & $\begin{array}{c}\text { Kelas } \\
\text { Eksperimen }\end{array}$ & $\begin{array}{c}\text { Kelas } \\
\text { Kontrol }\end{array}$ \\
\hline $\mathrm{n}$ & 35 & 35 \\
Sig (2-tailed) & 0.134 & 0.069 \\
\hline
\end{tabular}

Dari table 2 hasil uji normalitas terlihat memiliki nilai sig 0,134 dan 0,069 yang berarti bahwa data yang digunakan dalam penelitian ini adalah berdistribusi normal.

TABLE IIIII

UJI HOMOGENITAS

\begin{tabular}{cccc}
\hline Levene Statistic & df1 & df2 & Sig. \\
\hline 2.340 & 1 & 68 & .131 \\
\hline
\end{tabular}

Dari Tabel 3. hasil perhitungan dengan menggunakan SPSS terlihat bahwa nilai signifikan 0,131>0,05 artinya data variabel hasil belajar matematika berdasarkan kelas yang dilakukan penelitian ini memiliki arian yang sama atau dengan kata lain adalah homogen.

Pengujian hipotesis dengan menggunakan uji beda rerata (uji-t). Dengan:

Terima Ho : $\mu 1 \leq \mu 2$

Terima Ha $: \mu 1>\mu 2$

TABLE IVV

UJI T 


\section{A - - - Jurnal Pendidikan Matematika Indonesia \\ Volum 5 Nomor 1 bulan Maret 2020 Page 46 - 48 \\ p-ISSN: 2477-5967 e-ISSN: 2477-8443}

Hasil Belajar Matematika $\quad 0,001$

Perhitungan menggunakan SPSS pada tabel 4 didapatkan hasil dengan kesimpulan bahwa Ha diterima yang berarti terbukti bahwa hasil belajar yang didapatkan pada kelas kontrol dan eksperimen adalah berbeda, dimana kelas yang diberikan perlakuan dengan strategi pembelajaran aktif ICM disebut kelas kontrol. Sehingga dapat dikatakan adanya pengaruh dalam penggunaan strategi pembelajaran aktif terhadap hasil belajar matematika.

Mengulang materi pembelajaran menggunakan metode ICM (Index Card Match) dapat terjadi dengan cukup menyenangkan bagi siswa (Suprijono, 2013). Hal ini terlihat dari perhitungan uji pada hipotesis memperlihatkan bahwa adanya pengaruh yang positif penerapan strategi pembelajaran aktif ICM (Index Card Match) terhadap hasil belajar matematika siswa di kelas. Pengaruh positif yang terjadi dikarenakan metode ICM membuat siswa senang dan digunakan dengan cara mengulang materi yang telah diberikan (Istarani, 2016). Hasil perhitungan tersebut di perlihatkan dalam tabel 1. dimana nilai rata-rata hasil belajar matematika dengan penerapan metode ICM (Index Card Match) lebih besar jika dibandingkan kelas kontrol dalam pembelajarannya. Hal ini selaras dengan penelitian Yulianti yang menghasilkan bahwa model pembelajaran Index Card Match mampu meningkatkan hasil belajar siswa yang terlihat dengan adanya peningkatan sebesar $42 \%$ dari pencapaian awal.

Dari hasil perhitungan data, dengan memberikan perlakuan berbeda pada dua kelas menunjukkan bahwa ketika guru dapat memilih penggunaan cara yang sesuai dengan materi dan tujuan pembelajaran, maka dapat mempengaruhi hasil belajar siswa. Sesuai dengan hasil penelitian yang dilakukan oleh Mu'in bahwa keaktifan belajar siswa yang disebabkan oleh strategi ICM memberikan pengaruh positif dengan memberikan kenaikan menjadi $75,93 \%$. Guru dan siswa adalah komponen yang berpengaruh pada proses proses belajar dan mengajar. Hal yang dapat menyatukan informasi yang diberikan guru kepada siswa ialah metode pembelajaran, dengan penggunaan metode dalam pembelajaran yang tepat sehigga dapat mempermudah guru menyampaikan informasi dengan maksimal kepada siswa yang akan berdampak positif pada maksimalnya materi yang diterima siswa. Metode ini menuntut siswa bekerja sama antar siswa untuk saling mengajari satu sama lain dan menyelesaikan materi yang diajarkan oleh guru (Sitompul, 2018). Belajar yang baik adalah siswa mampu menangkap informasi dari guru secara baik dan jelas, siswa dengan fokus menyimak informasi dari guru sehingga dapat menerima dan menyimpan memori secara utuh, sehingga jika dilakukan evaluasi maka hasilnya akan tinggi.

Dari hal di atas, guru sebagai unsur terdepan dalam pembelajaran sangat berpengaruh dalam terciptanya suasana pembelajaran yang kondusif, hal tersebut juga didukung dengan penggunaan metode dan pemakaian media belajar yang tepat maka akan tercipta kelas yang baik dalam pembelajaran dan perdampak pada peningkatan hasil belajar siswa. Tidak hanya meningkatnya pembelajaran matematika namun dengan suasanaya yang menyenangkan dan kondusif dapat membantu siswa dalam menghilangkan pemikiran bahwa pelajaran matematika itu membosankan dan suatu pelajaran yang sulit karena tidak lepas dari suatu rumus yang abstrak.

\section{SIMPULAN}

Dengan digunakannya strategi pembelajaran aktif ICM (Index Card Match) pada proses belajar dan mengajar di kelas diharapkan adanya perubahan siswa kearah yang lebih baik. Perubahan yang dimaksud adalah siswa menjadi lebih senang dan tertarik pada materi yang diajarkan,dengan begitu pikiran siswa menjadi lebih terfokus dan akan meningkatkan hasil belajar siswa. Pada penelitian ini, terdapat perbedaan yang signifikan antara kelas eksperimen dibandingkan kelas control, hal ini dibuktikan dengan nilai $t_{\text {hit }}>t_{\text {tab }}(3,41>1,997)$.

\section{DAFTAR PUSTAKA}

A. Suprijono. (2013). COOPERATIVE LEARNING (Teori dan Aplikasi Paikem). Cet. 11. Yogyakarta: Pustaka Pelajar.

Anggraeni, Novita Eka. (2019). Strategi Pembelajaran Dengan Model Pendekatan Pada Peserta Didik Agar Tercapainya Tujuan Pendidikan Di Era Globalisasi. Scienceedu, II(June), Pp. 72-79.

Barlian, I. (2013). Begitu Pentingkah Strategi Belajar Mengajar Bagi Guru ?. Jurnal Forum Sosial, VI(01), Pp. 241-246.

Istarani. (2016). 58 Model Pembelajaran Inovatif: Referensi Guru dalam Menentukan Model Pembelajaran. Ed. Revisi. Medan: Media Persada.

Jaya, H. N. (2017). Keterampilan Dasar Guru Untuk Menciptakan Suasana Belajar Yang Menyenagkan. Didaktis: Jurnal Pendidikan Dan Ilmu Pengetahuan, 17(1), Pp. 23-35.

Mu'in, Mukhammad Samsul. (2010). Upaya Meningkatkan Prestasi Belajar Melalui Strategi Index Card Match pada Pembelajaran SKI Siswa Kelas III MI Negeri Krincing Tahun 2009/2010, Salatiga: Skripsi STAIN Salatiga.

Siregar, N. R. (2017). Persepsi Siswa Pada Pelajaran Matematika: Studi Pendahuluan Pada Siswa Yang Menyenangi Game. Prosiding Teтu Ilmiah X Ikatan Psikologi Perkembangan Indonesia, Pp. 224-232.

Sitompul, Dian Novianti. (2018). Pengaruh Metode Pembelajaran Index Card Match (ICM) Terhadap Hasil Belajar Akuntansi. Jupeko (Jurnal Pendidikan Ekonomi), Vol 3 No. 1. 1-15.

Yulianti, (2011). Skripsi: Meningkatkan Hasil Belajar Pendidikan Agama Islam melalui Index Card Match Kelas V SD Negeri 15 Mandonga Kota Kendari, Kendari: IAIN Kendari.

Zaini, H., Munthe, B. And Aryani, S. A. (2007). Strategi Pembelajaran Aktif. Cet. 6. Yogyakarta: Pustaka Instan Madani. 